\title{
Sustav oporezivanja alkohola u Europskoj uniji i Hrvatskoj
}

\author{
PETAR SOPEK Privredna banka Zagreb ${ }^{\mathrm{I}}$
}

Oporezivanje alkohola generira socijalne, zdravstvene i ekonomske učinke. No, glavni razlog uvođenja poreza gotovo uvijek su fiskalni učinci, odnosno povećanje javnih prihoda. Budući da za zemlje članice EU-a postoji Direktiva kojom se uređuju samo minimalne stope oporezivanja alkohola i alkoholnih pića, evidentne su brojne razlike u primjeni stopa trošarina i prihodima proračuna država članica od trošarina na alkohol. U sustavu trošarina na alkohol i alkoholna pića stoga ima prostora za daljnje usklađivanje stopa na razini EU-a, ali $i$ izuzeća i kategorizacije pojedinih proizvoda. Nadalje, potrebno je uspostaviti kvalitetne mehanizme za borbu protiv krijumčarenja te uskladiti ciljeve zdravstvene i socijalne politike s ciljevima poljoprivredne politike, posebice u poticanju proizvodnje vina. Hrvatske trošarine na alkohol i alkoholna pića u potpunosti su usklađene s minimalnim zahtjevima i stopama koje propisuje EU.

\section{UvOD}

Problem alkohola jedan je od najvažnijih svjetskih prioriteta u području javnog zdravstva. On je dokazani uzročnik oko 6o-ak različitih tipova bolesti i stanja, uključujući ozljede, mentalne, bihevioralne, imunološke i reproduktivne poremećaje, kardiovaskularne i mišićno-koštane bolesti, bolesti probavnog sustava, jetra i pluća, uzročnik raka itd. (Anderson i Baumberg, 2006:4). U Europi je alkohol na trećem mjestu uzročnika obolijevanja i smrtnosti, odmah iza duhana i visokog krvnog tlaka. Europska Unija (EU) je regija s najvišom potrošnjom alkohola u svijetu. Prosječna godišnja potrošnja po odrasloj osobi (starijoj od I5 godina) 2009. iznosila je I2,5 litara čistog alkohola, odnosno $27 \mathrm{~g}$ čistog alkohola ili otprilike tri pića dnevno, što je više nego dvostruko više od svjetskog prosjeka (WHO, 2OI2:I).

Uz porez na dodanu vrijednost (PDV), alkohol i alkoholna pića se i u EU-u i Hrvatskoj dodatno oporezuju trošarinom, koja se obračunava $u$ apsolutnom iznosu na definiranu trošarinsku osnovicu. Ciljevi primjene trošarina na alkohol mogu biti različiti - od poticanja smanjenja potrošnje (zdravstveni i socijalni motiv), poništavanja svih vanjskih ${ }^{2}$ i ukupnih društvenih troškova (ekonomski i socijalni motiv)

\footnotetext{
${ }^{\mathrm{I}}$ Navodi u tekstu isključivo su osobni stavovi autora te ni u kojem slučaju ne izražavaju stajalište ili mišljenje institucije u kojoj je zaposlen. ${ }^{2}$ Eksternalija ili eksterni/vanjski učinak je posljedica djelovanja jedne jedinke izravno na blagostanje druge jedinke, pri čemu se to djelovanje ne ostvaruje putem tržišnih cijena. Primjeri direktnih vanjskih učinaka generiranih potrošnjom alkohola su automobilska nesreća prouzročena vožnjom u pijanom stanju u kojoj nastrada neka druga osoba, štete na tuđoj imovini ili nasilje. Indirektan primjer vanjskih učinaka je trošak medicinskog liječenja problema uzrokovanih alkoholom koji se pokriva iz javnih
} 
ili prikupljanja prihoda za opće potrebe (fiskalni motiv). Brojne studije (Smith, 2005; Cnossen, 2006; Rabinovich i sur., 20I2) navode postojanje negativne elastičnosti potrošnje alkohola na cijenu, što znači da rast cijena alkoholnih pića inducira i smanjenje potrošnje. Elastičnost varira ovisno o vrsti alkoholnih pića; najmanja je uglavnom kod piva, a najveća u žestokih alkoholnih pića. Također, dugoročna cjenovna elastičnost potražnje za alkoholom viša je od kratkoročne, a ljudi koji tek povremeno piju cjenovno su osjetljiviji od onih koji piju češće (Cnossen, 2006:23-25). Drugim riječima, pitanje potrošnje značajno ovisi o navikama potrošača, pa se kod alkohola ne smije zanemariti ni pitanje ovisnosti. Neki od individualnih i vanjskih troškova konzumacije alkohola upravo nastaju zbog ovisničke naravi potrošnje, što problemu daje dodatnu dimenziju.

S obzirom na brojne razlike u primijenjenim stopama po pojedinim zemljama, očito je da ne postoji usuglašeno mišljenje o optimalnim iznosima trošarina kojima bi se poništili vanjski i ukupni društveni troškovi te umanjili ukupni negativni učinci potrošnje alkoholnih pića. To zapravo znači da je postojeći sustav oporezivanja alkoholnih pića utemeljen uglavnom na drugačijim načelima od navedenih, tj. vrlo često su upravo ekonomski ili - preciznije - fiskalni učinci glavni razlog uvođenja poreza.

U svakom slučaju, politika oporezivanja alkohola i alkoholnih pića trebala bi odražavati optimalnu integraciju svih željenih učinaka. Glavni cilj ovog rada je dati sažeti prikaz sustava oporezivanja alkohola $\mathrm{u}$ EU-u, usporediti ga $\mathrm{s}$ hrvatskim te pokazati najbitnije razlike među zemljama članicama. Nadalje, $\mathrm{u}$ radu će biti identificirani ključni nedostaci u postojećem europskom sustavu oporezivanja alkohola koji će vjerojatno biti važan faktor prilikom odlučivanja o budućem usklađivanju zakonodavstva.

\section{ZAKONSKI OKVIR OPOREZIVANJA ALKOHOLA}

Zajednički uređeno oporezivanje alkohola i alkoholnih pića za zemlje članice EU-a primjenjuje se od I. siječnja 1993. Direktiva vijeća od 19. listopada 1992. o usklađivanju strukture trošarina na alkohol i alkoholna pića, te na alkohol koji je sastojak drugih proizvoda (Council Directive 92/83/EEC) propisuje:

- vrste alkoholnih proizvoda koji se oporezuju (pivo, vino, fermentirani proizvodi koji nisu pivo ili vino, međuproizvodi i etilni alkohol sadržan u pićima);

- porezne osnovice;

- mogućnosti korištenja snižene stope za male neovisne pivarske proizvođače čija godišnja proizvodnja nije veća od 200.000 hektolitara, male neovisne destilerije čija godišnja proizvodnja nije veća od Io hektolitara, kao i mogućnost primjene snižene stope za određena pića;

- posebne postupke oporezivanja za određena područja Španjolske;

- dopuštenja izuzeća za neka pića u Velikoj Britaniji;

- izuzeće od oporezivanja alkohola koji nije namijenjen za pića, odnosno izuzeće za denaturirani alkohol i alkohol koji se upotrebljava u farmaceutskoj, kozmetičkoj, prehrambenoj i sličnim proizvodnjama.

Direktivom vijeća od I9. listopada 1992. o usklađivanju stopa poreza na alkohol i alkoholna pića (Council Directive 92/84/EEC) propisuju se minimalne stope za alkohol i alkoholna pića3:

- 550 eura po hektolitru čistog alkohola za čisti alkohol sadržan u ostalim alkoholnim pićima, odnosno I.Ooo eura po hektolitru čistog alkohola za zemlje koje su u trenutku donošenja Direktive već primjenjivale trošarine na te proizvode u iznosu većem od I.ooo eura;

- 45 eura po hektolitru za međuproizvode (npr. desertna vina, likerska vina);

- nulta stopa za vino i pjenušce;

- o,748 eura po hektolitru (ovisno u koncentraciji sladovine) ili I,87 eura po hektolitru (ovisno o sadržaju alkohola) za pivo.

sredstava. Postoji i treća kategorija koja se realizira kroz porezni sustav, budući da potrošnja alkohola može imati posljedice na potrošačev dohodak i potrošnju (Smith, 2005:68).

${ }^{3}$ Osim minimalnih stopa za alkohol i alkoholna pića, Direktivom vijeća 92/84/EEC propisuju se i posebni postupci oporezivanja za određena područja Grčke, Italije i Portugala. 
Navedene dvije direktive nadopunjuje i Uredba komisije (EZ) br. 3199/93 od 22. studenog 1993. o uzajamnom priznavanju postupaka potpunog denaturiranja alkohola radi izuzeća od trošarine, kojom se provodi čl. 27.(I)(a) Direktive vijeća 92/83/EEC za potpuno denaturiranje alkohola i navode različite formulacije denaturanata u zemljama članicama. Osim navedenog zakonskog okvira, specifična pitanja, poput dopuštenja za korištenje sniženih stopa trošarina na određene proizvode i regije u Francuskoj i Portugalu, riješena su zasebnim odlukama.

Zakonski okvir zajednički uređenog oporezivanja alkohola i alkoholnih pića za zemlje članice EU-a propisuje tek minimalne stope trošarina po pojedinim vrstama alkoholnih pića. Zemlje članice mogu slobodno odrediti vlastite stope trošarina iznad minimalnih, u skladu s vlastitim nacionalnim politikama. Zbog toga na EU razini postoje značajne razlike u primjeni općih stopa (usporedba aktualnih općih stopa trošarina po zemljama članicama prikazana je u grafikonima DI-D5 u Dodatku), kao i korištenja mogućnosti primjene sniženih stopa. Zapravo se ni ne može govoriti o zajednički uređenom oporezivanju alkohola na EU razini, u pravom smislu te riječi.

Definicija oporezivih proizvoda u EU-u provodi se sukladno Kombiniranoj nomenklaturi proizvoda te je izuzetno bitna zbog primjene adekvatnog tretmana prilikom oporezivanja, ali i zbog ostalih potreba statističkih i carinskih službi. Klasifikacija Kombinirane nomenklature alkoholnih pića po kategorijama iz Direktive 92/83/EEC prikazana je u tablici I.

Tablica I.

Klasifikacija alkoholnih pića sukladno Direktivi 92/83/EEC i Kombiniranoj nomenklaturi

\begin{tabular}{|c|c|c|c|c|c|c|c|c|c|c|c|}
\hline \multicolumn{2}{|c|}{ Kombinirana nomenklatura } & \multicolumn{2}{|c|}{ Pivo } & \multicolumn{2}{|c|}{ Vina } & \multicolumn{2}{|c|}{$\begin{array}{c}\text { Fermentirana } \\
\text { pića }\end{array}$} & \multicolumn{2}{|c|}{ Međuproizvodi } & \multicolumn{2}{|c|}{$\begin{array}{l}\text { Etilni } \\
\text { alkohol }\end{array}$} \\
\hline 2203 & Pivo dobiveno od slada & $\mathrm{X}$ & & & & & & & & & \\
\hline $22 \mathrm{O} 4$ & $\begin{array}{l}\text { Vino od svježeg grožđa, } \\
\text { uključujući pojačana vina; } \\
\text { mošt od grožđa, osim mošta } \\
\text { iz tarifnog broja } 2009\end{array}$ & & & $\mathrm{X}$ & $\mathrm{X}$ & $\mathrm{X}$ & $\mathrm{X}$ & $\mathrm{X}$ & $\mathrm{X}$ & & $\mathrm{X}$ \\
\hline $22 \mathrm{O} 5$ & $\begin{array}{l}\text { Vermut i ostala vina od svježeg } \\
\text { grožđa, aromatizirana biljem ili } \\
\text { aromatskim tvarima }\end{array}$ & & & $\mathrm{X}$ & $\mathrm{X}$ & $\mathrm{X}$ & $\mathrm{X}$ & $\mathrm{X}$ & $\mathrm{X}$ & & $\mathrm{X}$ \\
\hline 2206 & $\begin{array}{l}\text { Ostala fermentirana pića } \\
\text { i mješavine fermentiranih } \\
\text { i bezalkoholnih pića, koja nisu } \\
\text { drugdje navedena }\end{array}$ & & $\mathrm{X}$ & & & $\mathrm{X}$ & $\mathrm{X}$ & $\mathrm{X}$ & $\mathrm{X}$ & & $\mathrm{X}$ \\
\hline $22 \mathrm{O}$ & $\begin{array}{l}\text { Nedenaturirani etilni alkohol, } \\
\text { s volumnim udjelom alkohola od } \\
\text { 80\% vol. ili većim; etilni alkohol } \\
\text { i ostali alkoholi, denaturirani, } \\
\text { bilo koje jačine }\end{array}$ & & & & & & & & & $\mathrm{X}$ & \\
\hline 2208 & $\begin{array}{l}\text { Nedenaturirani etilni alkohol, } \\
\text { s volumnim udjelom alkohola } \\
\text { manjim od 8o\% vol.; rakije, likeri } \\
\text { i ostala alkoholna pića }\end{array}$ & & & & & & & & & $\mathrm{X}$ & \\
\hline \multicolumn{2}{|c|}{ Udio alkohola (u \%) } & $>0,5$ & $>0,5$ & $\begin{array}{l}>\mathrm{I}, 2 \\
<\mathrm{I} 5\end{array}$ & $\begin{array}{l}>\mathrm{I} 5 \\
<\mathrm{I} 8\end{array}$ & $\begin{array}{l}>\mathrm{I}, 2 \\
<\mathrm{IO}\end{array}$ & $\begin{array}{l}>\mathrm{IO} \\
<\mathrm{I} 5\end{array}$ & $\begin{array}{l}>I, 2 \\
<22\end{array}$ & $>5,5$ & $>I, 2$ & $>22$ \\
\hline
\end{tabular}

Izvor: London Economics (20IO)

U Hrvatskoj se trošarinski sustav oporezivanja alkohola i alkoholnih pića uređuje Zakonom o trošarinama, ZOT-om (NN 83/o9, III/I2 i 22/I3), a postupanje u njegovoj primjeni regulirano je Pravilnikom o trošarinama (NN I/IO.). Definicije oporezivih proizvoda iz hrvatskog zakonodavnog okvira također su usklađene s Kombiniranom nomenklaturom kao što je prikazano u tablici I. 
Trošarinske osnovice i visine trošarina definirane su ovako:

- Trošarinska osnovica na pivo je i\% vol. udjela stvarnog alkohola sadržanog u jednom hektolitru gotovog proizvoda, a iznosi 40 kuna.

- Trošarinska osnovica na vino, ostala pića dobivena vrenjem - osim piva i vina - te međuproizvode je jedan hektolitar gotovog proizvoda. Trošarina za mirna i pjenušava vina te ostala pića dobivena vrenjem - osim piva i vina - iznosi nula kuna. Trošarina na međuproizvode s volumnim udjelom stvarnog alkohola od $15 \%$ i većim, iznosi 800 kuna po hektolitru gotovog proizvoda, a za međuproizvode s volumnim udjelom stvarnog alkohola manjim od $15 \%$ vol. iznosi 500 kuna po hektolitru gotovog proizvoda.

- Trošarinska osnovica na etilni alkohol je jedan hektolitar čistog alkohola izraženoga u volumnim postocima mjerenim pri temperaturi od $20^{\circ} \mathrm{C}$, a iznosi 5.300 kuna.

Može se zaključiti da su hrvatske trošarine na alkohol i alkoholna pića u potpunosti usklađene s minimalnim zahtjevima i stopama koje propisuje EU. Kao i u europskom zakonodavstvu, postoje porezna oslobođenja od plaćanja poreza kao što je oslobođenje pri izvozu, za alkohol koji se upotrebljava u farmaceutskoj, kozmetičkoj, prehrambenoj i sličnim proizvodnjama. Novi ZOT (NN 22/13.), kojime se u pravni poredak Hrvatske prenose Direktiva Vijeća 92/83/EEZ i Direktiva Vijeća 92/84/EEZ, većim dijelom stupa na snagu danom ulaska Hrvatske $\mathrm{u} \mathrm{EU}^{4}$. Visina trošarina na alkohol i alkoholna pića nije promijenjena novim Zakonom.

\section{USPOREDNA ANALIZA PRIHODA OD TROŠARINA}

Važnost prihoda od trošarina na alkohol i alkoholna pića značajno ovisi o nacionalnoj politici oporezivanja alkohola i alkoholnih pića, poljoprivrednoj, zdravstvenoj i ekološkoj politici, tradiciji konzumacije i ukupne potrošnje alkoholnih pića, obujmu legalne prekogranične trgovine i ilegalnih aktivnosti poput krijumčarenja i ostale porezne evazije. Stoga se udio prihoda od trošarina na alkohol i alkoholna pića u ukupnim poreznim prihodima značajno razlikuje po zemljama članicama, što je prikazano na grafikonu I.

\section{Grafikon I.}

Udio prihoda od trošarina na alkohol i alkoholna pića u ukupnim poreznim prihodima (bez doprinosa) u 20II. (u \%)

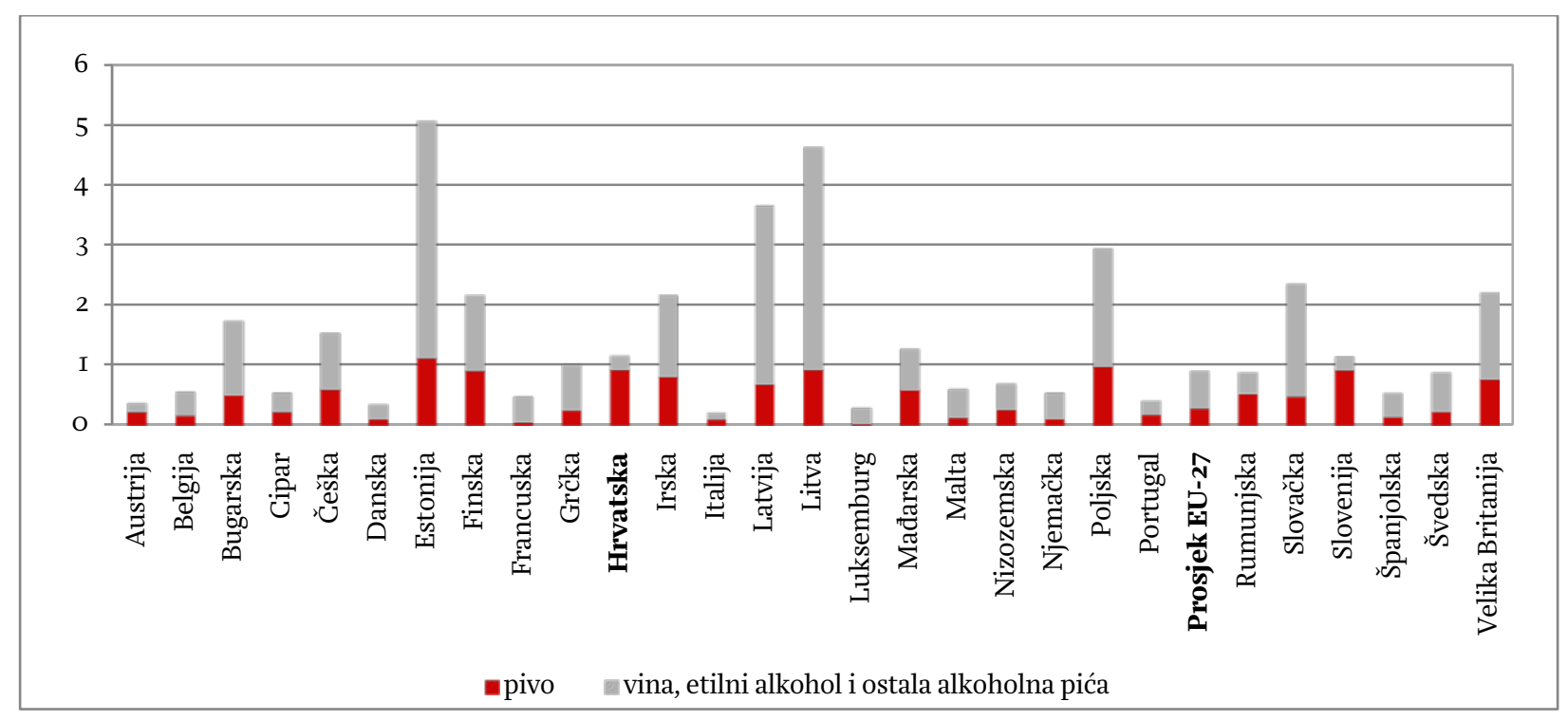

Izvor: Prilagodba autora temeljem podataka iz European Commission (2OI2a), Eurostata i Ministarstva financija RH

\footnotetext{
${ }^{4}$ Cijela Glava XVI (čl. 53-69.) u kojoj se propisuju temelji oporezivanja alkohola i alkoholnih pića (predmet oporezivanja, trošarinska osnovica, visina trošarine, oslobođenja od plaćanja trošarine itd.) stupa na snagu danom pristupanja hrvatske EU-u.
} 
Bez obzira na značajne razlike među promatranim zemljama, evidentno je da su prihodi od trošarina na alkohol i alkoholna pića relativno mali u odnosu na ukupne porezne prihode, odnosno ukupne prihode proračuna zemalja članica. Prosječan udio prihoda od trošarina na alkohol i alkoholna pića zemalja članica EU-27 u ukupnim poreznim prihodima (bez doprinosa) iznosio je 0,9I\% u 20II., u ukupnim prihodima opće države o,54\% te u BDP-u 0,24\%. Hrvatska je u tom kontekstu malo iznad prosjeka EU-27, s udjelom prihoda od trošarina na alkohol $\mathrm{i}$ alkoholna pića u ukupnim poreznim prihodima od $\mathrm{I}, \mathrm{I} 8 \%$, $\mathrm{u}$ ukupnim prihodima opće države $0,67 \%$ i u BDP-u o,25\%. Grafikon 2 prikazuje strukturu prihoda od harmoniziranih trošarina u EU-u $20 \mathrm{OI}^{5}$.

\section{Grafikon 2.}

Struktura prihoda od harmoniziranih trošarina zemalja EU-27 i Hrvatske u 20II. (u \%)

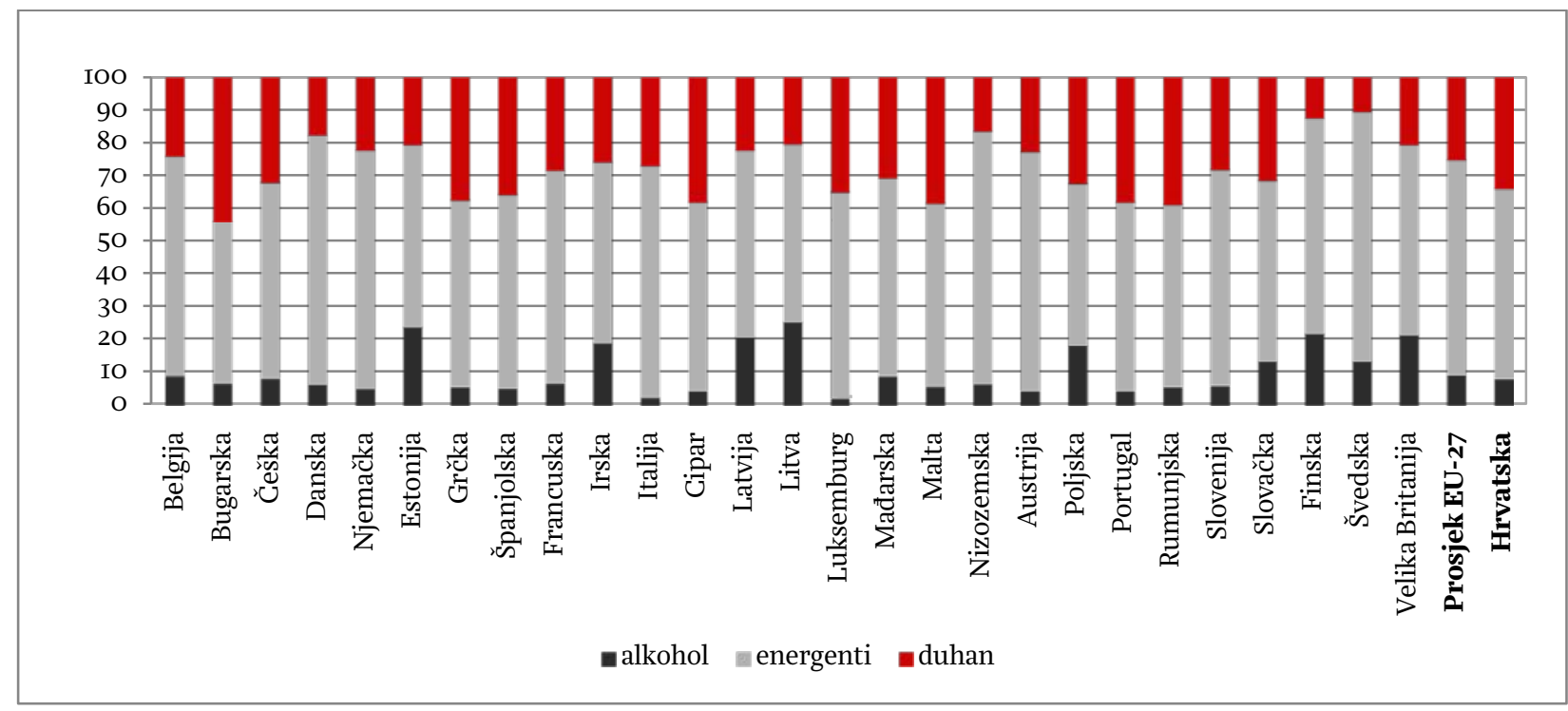

Izvor: Prilagodba autora temeljem podataka iz European Commission (2OI2a; 20I2b; 2OI2c) i Ministarstva financija RH

Prihodi od trošarina na alkohol u promatranih EU 27 zemalja - čine manje od Io\% ukupnih prihoda od harmoniziranih trošarina (9,4\%), što je značajno manje od duhanskih proizvoda (25,1\%) i energenata (65,5\%). Najviši udjeli trošarina na alkohol u harmoniziranim trošarinama zabilježeni su u Litvi (25,4\%), Estoniji (23,8\%), Finskoj (2I,7\%) i Velikoj Britaniji (2I,3\%), a najmanji u Luksemburgu (2,2\%) i Italiji (2,5\%). Udio prihoda od trošarina na alkohol u ukupnim prihodima od harmoniziranih trošarina u Hrvatskoj nešto je niži od europskog prosjeka i iznosi 8,I\%, a također je značajno niži od duhanskih proizvoda $(33,8 \%)$ i energenata $(58,1 \%)$.

\footnotetext{
${ }^{5}$ Harmonizirane trošarine zemalja EU-a označavaju trošarine na skupinu proizvoda (alkohol i alkoholna pića, duhanske proizvode i energente), za koje je zakonski okvir donesen prilikom uspostavljanja Zajedničkog tržišta I. siječnja I993. Prihodi od tih vrsta trošarina predstavljaju najveći udio ukupnih prihoda od trošarina. Prema podacima iz baze podataka Taxes in Europe (European Commission), jedino je u slučaju Danske i Velike Britanije udio neharmoniziranih trošarina relativno značajan u ukupnim prihodima od trošarina (I2\% i i $4 \%$ ).
} 


\section{Grafikon 3.}

Odnos godišnje potrošnje piva (u litrama čistog alkohola) i prihoda proračuna od trošarina na pivo (u eurima) po jednoj odrasloj osobi u 2009.

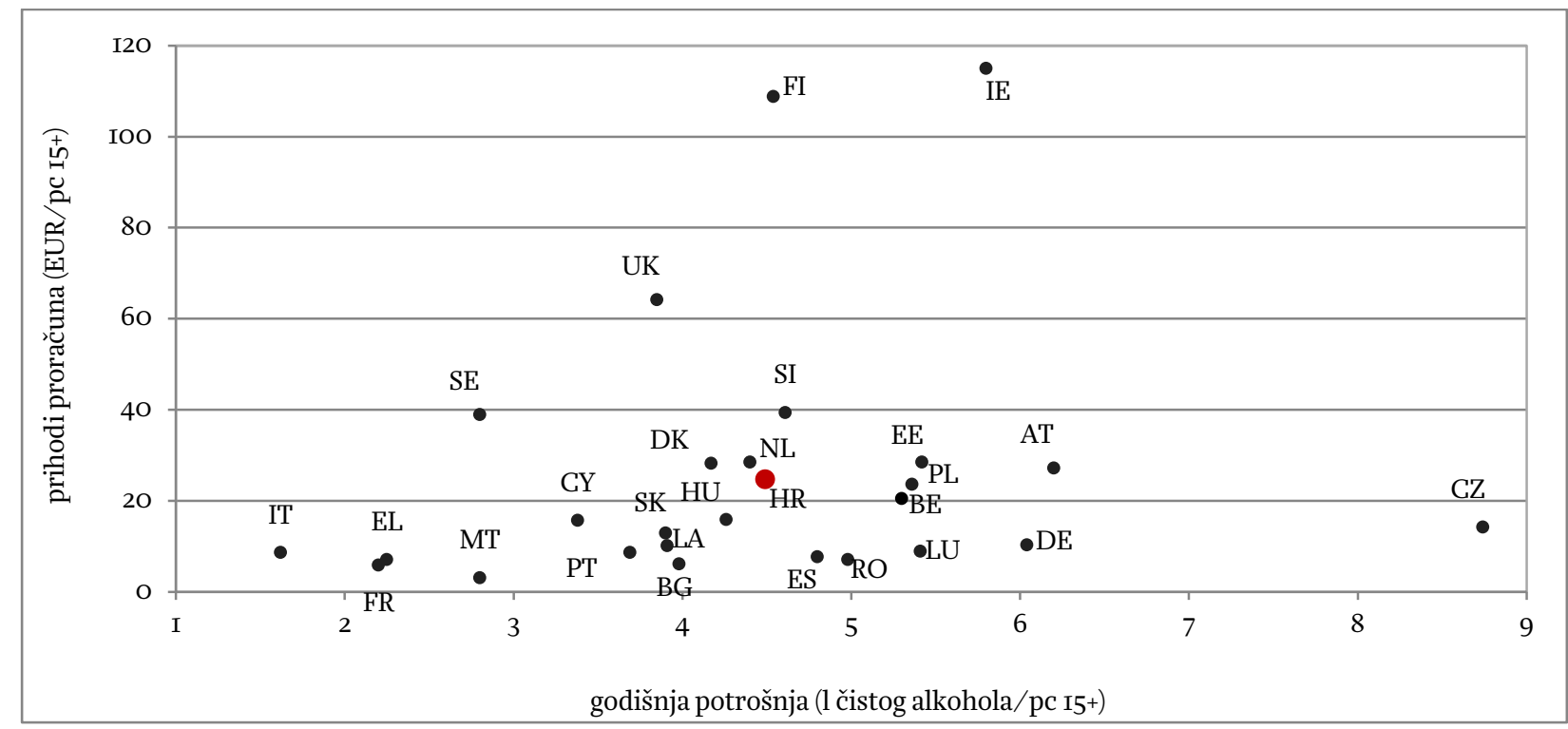

Izvor: Obrada autora temeljem podataka iz publikacije European Commission (20I2a) te baze podataka Global Health Observatory, Eurostat, Ministarstvo financija RH

\section{Grafikon 4 .}

Odnos godišnje potrošnje alkohola i alkoholnih pića različitih od piva (u litrama čistog alkohola) i prihoda proračuna od trošarina na alkohol i alkoholna pića bez piva (u eurima) po jednoj odrasloj osobi u 2009.

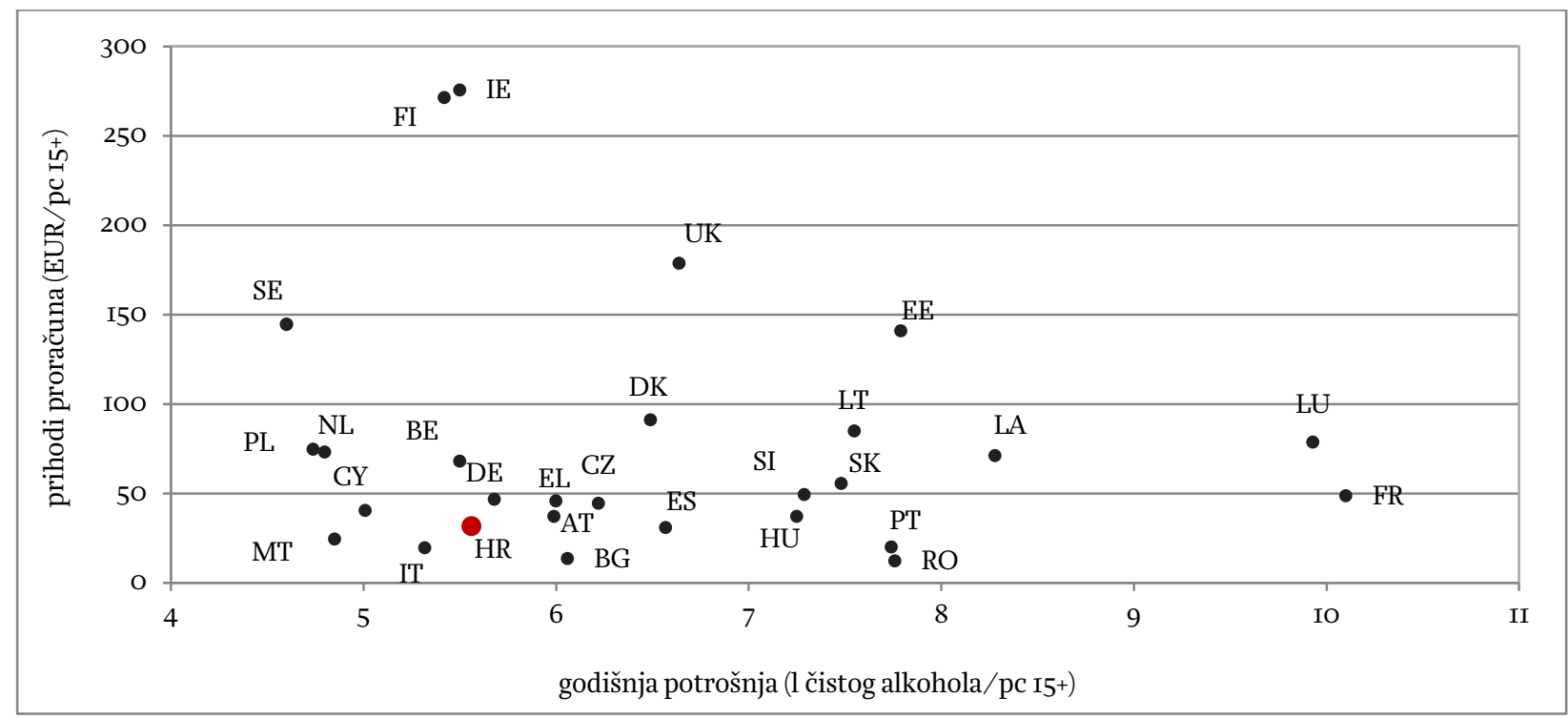

Izvor: Obrada autora temeljem podataka iz publikacije European Commission (2012a) te baze podataka Global Health Observatory, Eurostat, Ministarstvo financija RH

Primijenjene stope trošarina na pivo značajno se razlikuju od zemlje do zemlje (grafikon Di u Dodatku), a u pojedinim se zemljama primjenjuje i velik broj različitih stopa što dodatno komplicira trošarinski sustav. To se posebice odnosi na snižene stope za male neovisne pivarske proizvođače, pri čemu su razlike u trošarinama definirane u odnosu na godišnju proizvodnju. Na visinu stopa utječe i razvijenost i značaj pivarske industrije pa su stope u zemljama veće pivarske proizvodnje (Njemačka, Belgija i Češka) znatno niže. Najviše stope trošarina imaju Irska, Velika Britanija, Švedska i Finska, a upravo one i ubiru najviše prihoda od trošarina na pivo. Na grafikonu 3 posebno se ističe Češka s iznimno visokom potrošnjom piva od čak 8,7 litara čistog alkohola po odrasloj osobi godišnje, ali i relativno niskim 
prihodima proračuna od trošarina na pivo. To je rezultat primjene niske opće stope od I,28 eura po I stupnju Plato skale (koncentracija sladovine), sadržanog u hektolitru gotovog proizvoda te dodatnih pet sniženih stopa koje se primjenjuju za male neovisne pivarske proizvođače.

Iz grafikonâ D2-D5 prikazanima u Dodatku, vidljivo je da Irska, Velika Britanija, Švedska i Finska općenito primjenjuju najviše opće stope na alkohol i alkoholna pića različita od piva. Grafikon 4. pokazuje da upravo te zemlje ujedno ubiru i najviše prihoda od trošarina na alkohol i alkoholna pića različita od piva. Luksemburg i Francuska, dvije europske zemlje koje su najveći potrošači vina s više od 7 litara čistog alkohola po odrasloj osobi godišnje, ujedno primjenjuju iznimno niske trošarine na vina što logično dovodi i do relativno niskih prihoda od trošarina u odnosu na potrošnju.

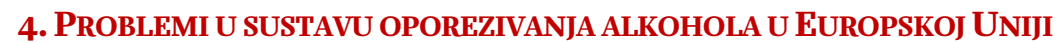

Iako trošarine na alkohol i alkoholna pića spadaju u harmonizirane trošarine, za zemlje članice EU-a postoji tek Direktiva kojom se uređuju isključivo minimalne stope oporezivanja alkohola i alkoholnih pića, te su stoga evidentne brojne razlike među zemljama članicama u primjeni stopa trošarina. Navedene različite politike oporezivanja među zemljama članicama dovode do različitih razina cijena alkohola i alkoholnih pića. Indeksi cijena alkoholnih pića po zemljama članicama EU-a prikazani su na grafikonu 5 .

\section{Grafikon 5 .}

Indeks cijena alkoholnih pića, 20II. (EU-27 = IOO)

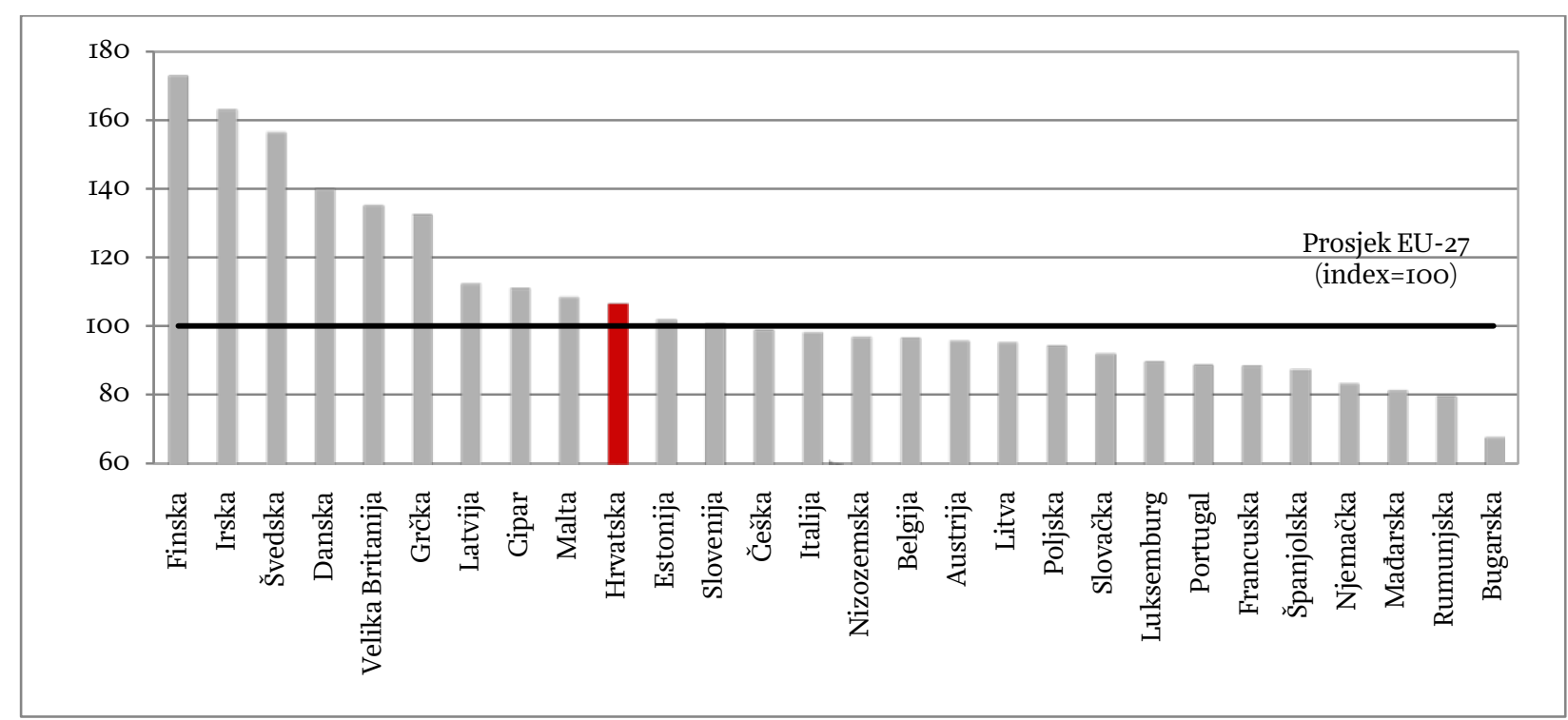

Izvor: Eurostat baza podataka, prilagodba autora

Zemlje članice s najvišim stopama trošarina na alkohol i alkoholna pića ujedno imaju i najviše cijene tih proizvoda, značajno iznad prosjeka EU-27. Indeks cijena alkoholnih pića također pokazuje da Hrvatska ima više cijene alkoholnih pića od prosjeka zemalja članica EU-a i više od svih zemalja članica s kojima graniči. Međutim, razlike u cijenama među zemljama članicama nisu nužno uzrokovane trošarinama, jer značajan utjecaj na cijene može imati i PDV koji se u konačnici obračunava na maloprodajnu cijenu proizvoda. Na alkohol i alkoholna pića primjenjuje se opća stopa PDV-a, koja u EU-u značajno varira od najnižih $15 \%$ u Luksemburgu do najviših 27\% u Mađarskoj (European Commission, 2013b). Hrvatska stopa PDV-a od 25\% jedna je od najviših u EU-u i viša od stopa u susjednim zemljama (osim Mađarske). London Economics (20I0:5I) pokazuje da je stopa oporezivanja samo jedan od razloga postojanja razlika $\mathrm{u}$ cijenama. Na cijene proizvoda utječu i tečajne razlike, dostupnost proizvoda (primjerice zbog razlike u ukusima potrošača ili u kupovnoj moći), troškovi proizvodnje (transport, distribucija, konkurencija i sl.) i djelotvornost poreznog sustava (tj. krijumčarenje). Međutim, Rabinovich i sur. (2012:138-I39) na 
primjeru piva i žestokih pića pokazuju da je visina trošarine pozitivno korelirana s cijenom proizvoda, odnosno da više cijene trošarina ujedno impliciraju i više cijene proizvoda.

Svojevrstan problem $\mathrm{u}$ zajedničkom oporezivanju alkohola i alkoholnih pića predstavlja realna vrijednost minimalnih trošarina. Čl. 8. Direktive vijeća od I9. listopada 1992. o usklađivanju stopa poreza na alkohol i alkoholna pića (Council Directive 92/84/EEC), predviđeno je preispitivanje minimalnih stopa trošarina svake dvije godine, vodeći računa o pravilnom funkcioniranju unutarnjeg tržišta, konkurenciji između različitih kategorija alkoholnih pića, realnoj vrijednosti trošarinskih stopa i širim ciljevima EU-a. Međutim, od trenutka uvođenja minimalnih stopa trošarina 1993. do danas, njihova je vrijednost ostala nepromijenjena, iako se već u nekoliko navrata preporučivalo usklađivanje $s$ promjenom razine cijena. U Izvješću o trošarinskim stopama koje se primjenjuju na alkohol i alkoholna pića (Commission of the European Communities, 2004) predloženo je razmatranje revalorizacije minimalnih stopa za $24 \%$, te je istaknuto da je ta revalorizacija potrebna kako bi se izbjeglo da trošarinske stope s vremenom postanu beznačajne. Dvije godine kasnije, Prijedlogom izmjena i dopuna Direktive vijeća 92/84/EEC (Proposal for Council Directive amending Directive 92/84/EEC), predloženo je povisivanje minimalnih stopa za 31\% s početkom primjene od I. siječnja 2008., ali ni do tih izmjena nije došlo. Prema podacima Eurostata od 1996. do 2012. cijene alkoholnih pića mjerene harmoniziranim indeksom potrošačkih cijena zemalja EU-27 porasle su za 36,5\%, dok su ukupne razine cijena porasle za 6o,2\%. Svakako se može očekivati da će u bližoj budućnosti biti nužna revalorizacija minimalnih stopa trošarina na razini cijele EU.

U vezi s (višim) razinama cijena javlja se još jedna ekonomski nepovoljna pojava - rast legalne prekogranične trgovine, a posebice ilegalnih aktivnosti poput krijumčarenja i ostale porezne evazije. London Economics (2010:56) pokazuje da su zemlje s najvišim diferencijalima cijena ujedno i zemlje s najvišim udjelima prekogranične trgovine alkohola. Problem je posebno naglašen u pojedinim zemljama EU-a, npr. Danskoj, Švedskoj, Finskoj (London Economics, 20IO:56). Prema High Level Group on Fraud in the Tobacco and Alcohol Sectors (1998:20) proračunski gubici zemalja EU-I5 zbog ilegalnog tržišta procijenjeni su 1996. na iznos od ukupno I,5 milijardi eura. Međutim, Rabinovich i sur. (2OI2:I5I) navode da je neto učinak promjena cijena alkoholnih proizvoda povoljan, odnosno da korist od smanjenja štete povezane sa smanjenom potrošnjom alkohola uslijed rasta cijena nadilazi troškove prelaska dijela potrošnje iz formalnog u neformalno gospodarstvo. Značaj problema krijumčarenja, posebice uz istočne granice EU-a, prepoznala je i Europska Komisija, identificirajući mnoštvo, uglavnom kratkoročnih i srednjoročnih aktivnosti uz pomoć zemalja članica, Rusije i zemalja istočnog partnerstva (Armenija, Azerbajdžan, Bjelorusija, Gruzija, Moldavija i Ukrajina). Europska Komisija navodi da zemlje članice s visokim trošarinama moraju uspostaviti učinkovite interne kontrole, a sve zemlje članice EU-a koje graniče s trećim zemljama moraju pojačati kontrole i spriječiti krijumčarenja iz susjednih zemalja, te na taj način doprinijeti zaustavljanju odljeva iz njihovih vlastitih teritorija (European Commission, 20Ir:4). Ulaskom Hrvatske u EU velik dio hrvatskog graničnog teritorija će predstavljati i granicu EU-a s trećim zemljama, pa je stoga važna pojačana kontrola na hrvatskim državnim granicama, što je ujedno i jedan od zahtjeva za ispunjavanje schengenskih standarda. Međutim, ZOT donosi i nove, detaljnije odredbe o provedbi nadzora (učinkovitiji pravni okvir za suzbijanje, sprečavanje i sankcioniranje nezakonitosti i porezne evazije) i sveobuhvatnije mjere i aktivnosti u sprečavanju počinjenja prekršajnih djela i kažnjavanju počinitelja (Kuliš, 20I3:9).

Premda se klasificiranje oporezivih proizvoda provodi sukladno Kombiniranoj nomenklaturi u cijelom EU-u, definicija i jednak porezni položaj alkoholnih proizvoda još je uvijek pitanje koje nije do kraja riješeno unatoč brojnim naporima za njihovim usklađivanjem. Studija London Economics (20I0:68-73) identificirala je dva ključna problema u postojećem sustavu klasifikacije. Prvi se problem odnosi na nejasan porezni tretman u slučajevima kad se etilni alkohol dodaje fermentiranim pićima. U drugom je slučaju upitan porezni tretman proizvoda podvrgnutih procesu pročišćavanja (ultra filtracija, obrnuta osmoza i slično) i proizvoda dobivenih korištenjem pročišćenog alkohola. Detaljna analiza i 
karakterizacija alkoholnih proizvoda koju su proveli Segebarth i sur. (2008:3) ukazuje da je temeljem analitičkih metoda gotovo nemoguće stvoriti općenite modele koji bi bili u potpunosti primjenjivi na sve zemlje članice te sugerira pojedinačni pristup klasificiranja u svakoj zemlji kao jedini mogući način u kontekstu postojeće regulative.

Uzimajući u obzir šire ciljeve Ugovora o EU-u, pri oporezivanju alkohola i alkoholnih pića nužno je imati sve više na umu i ciljeve zdravstvene i poljoprivredne politike, premda ih neke članice pri određivanju svojih stopa još nisu potpuno uključile. S obzirom na poljoprivrednu politiku, još je uvijek sporno pitanje oporezivanja vina. Od 27 trenutnih članica EU-a, I2 ih primjenjuje trošarine na vino. Većina zemalja koje su poznati proizvođači vina, baš kao i Hrvatska, ne primjenjuju trošarine na vino ili ih pak oporezuju iznimno malom stopom (primjerice Francuska). Iako je propisana i mogućnost neoporezivanja pjenušavih vina, za razliku od oporezivanja vina, trošarine na njih primjenjuje čak I7 zemalja članica EU-a. Međutim, sporno je pitanje razlike u poreznom tretmanu stolnih vina i pjenušavih pića zato što se pjenušava pića u nekim zemljama tradicionalno smatraju luksuznim proizvodima (npr. u Njemačkoj i Austriji), pa su opterećena mnogo višom poreznom stopom (Kuliš, 2005:34). Proizvodnja vina dodatno se potiče potporama unutar Zajedničke poljoprivredne politike EU-a. Ciljevi su im poticanje razvoja konkurentnosti europskih vinara, zadovoljavanje potražnje i eliminacija rasipnih javnih intervencija na tržištu vina, a godišnji iznosi nisu beznačajni ${ }^{6}$. Time tržišna i politička važnost tih potpora svakako otežava napredak iz perspektive javnog zdravstva, odnosno poticanja smanjenja konzumacije.

\section{ZAKLJUČAK}

Oporezivanje alkohola generira razne socijalne, zdravstvene i ekonomske učinke. Međutim, fiskalni učinci, odnosno povećanje javnih prihoda, gotovo uvijek predstavljaju glavni razlog uvođenja poreza. Za zemlje članice EU-a postoji Direktiva kojom se određuju samo minimalne stope oporezivanja alkohola i alkoholnih pića te su stoga evidentne brojne razlike među zemljama članicama u primjeni stopa trošarina. Zemlje koje općenito primjenjuju najviše stope trošarina na alkoholna pića su Irska, Velika Britanija, Švedska i Finska, a one ujedno ubiru i najviše prihoda od trošarina. Zemlje u kojima postoji snažna industrija proizvodnje alkoholnih pića, kao što je Francuska za vino i Češka za pivo, podložnije su različitim lobijima interesnih skupina pa uobičajeno imaju i niže propisane stope trošarina. To se manifestira i u obliku nižih prihoda državnog proračuna.

Osim razlike $u$ primjeni stopa trošarina koje utječu i na razlike $u$ cijenama među zemljama članicama, problem u zajedničkom oporezivanju alkohola i alkoholnih pića unutar EU-a predstavlja i realna vrijednost minimalnih trošarina, budući da je nominalan iznos minimalnih trošarina ostao isti od uvođenja minimalnih stopa 1993. pa sve do danas. Od 1996. do 2012. cijene alkoholnih pića unutar EU-27 u prosjeku su porasle za 36,5\%, dok su ukupne razine cijena porasle za 6o,2\%. Radi uspostavljanja ekonomske ravnoteže na internom tržištu EU te postizanja zdravstvenih, socijalnih i fiskalnih ciljeva zajedničkog oporezivanja alkohola nužna je revalorizacija minimalnih stopa trošarina na razini EU-a, uz kontinuirano usklađivanje minimalnih stopa barem za godišnju stopu inflacije.

Velik problem sustava oporezivanja alkohola predstavlja gubitak prihoda od trošarina zbog legalne prekogranične prodaje i ilegalnih aktivnosti poput krijumčarenja. Stoga sve zemlje članice, a posebice one s visokim trošarinama moraju uložiti dodatne napore za uspostavu pravovaljanih internih kontrola. Sve zemlje članice EU-a koje graniče s trećim zemljama moraju pojačati kontrole i interne potrošnje i krijumčarenja iz susjednih zemalja te na taj način doprinijeti zaustavljanju odljeva iz njihovih teritorija.

U narednom razdoblju svakako valja riješiti i otvoreno pitanje nejasnih poreznih tretmana $u$ slučajevima kad se etilni alkohol dodaje fermentiranim pićima te kod proizvoda podvrgnutih procesu

\footnotetext{
${ }^{6}$ Anderson i Baumberg (2006:343) navode da godišnji iznos potpora za proizvodnju vina iznosi I,5 mlrd. eura.
} 
pročišćavanja i proizvoda dobivenih korištenjem pročišćenog alkohola. Nadalje, nužno je sve više imati na umu i ciljeve zdravstvene i socijalne politike te ih uskladiti s ciljevima poljoprivredne politike, osobito u kontekstu poticanja proizvodnje vina. Ova pitanja iziskuju dodatne analize jer mogu dovesti (i vjerojatno dovode) do određenih ekonomskih neravnoteža.

Trošarine na alkohol i alkoholna pića u Hrvatskoj već su u potpunosti usklađene s minimalnim zahtjevima i stopama EU-a. ZOT ne predviđa nikakve snižene stope za male proizvođače piva koje primjenjuju gotovo sve članice Unije. Ulaskom Hrvatske u EU na snagu će stupiti odredbe novog ZOT-a (NN 22/I3.) o oporezivanju alkohola i alkoholnih pića koje ne donose nikakve promjene u pogledu visina trošarina na alkohol i alkoholna pića.

\section{LITERATURA}

Anderson, P. i Baumberg, B., 2006. Alcohol in Europe - A public health perspective. London: Institute of Alcohol Studies.

Cnossen, S., 2006. Alcohol Taxation and Regulation in the European Union. CESifo Working Paper, br. I82I.

Commission of the European Communities, 2004. Report from the Commission to the Council, the European Parliament and the European Economic and Social Committee on the rates of excise duty applied on alcohol and alcoholic beverages. Bruxelles: Commission of the European Communities.

Commission Regulation (EC) No 3199/93 of 22 November 1993 on the mutual recognition of procedures for the complete denaturing of alcohol for the purposes of exemption from excise duty. Bruxelles: European Commission.

Council Directive 92/83/EEC of 19 October 1992 on the harmonization of the structures of excise duties on alcohol and alcoholic beverages. Bruxelles: European Commission.

Council Directive 92/84/EEC of 19 October 1992 on the approximation of the rates of excise duty on alcohol and alcoholic beverages. Bruxelles: European Commission.

European Commission, 20II. Commission Anti-fraud Strategy - Action plan to fight against smuggling of cigarettes and alcohol along the EU Eastern border. Bruxelles: European Commission.

European Commission, 20I2a. Excise duty tables - Tax Receipts Alcoholic Beverages - July 20I2. Bruxelles: European Commission.

European Commission, 20I2b. Excise duty tables - Tax Receipts Manufactured Tobacco - July 2 OI2. Bruxelles: European Commission.

European Commission, 20I2c. Excise duty tables - Tax Receipts Energy products and Electricity - July 2012. Bruxelles: European Commission..

European Commission, 2013a. Excise duty tables - Part I Alcoholic Beverages - Situation at Ist January 2013. Bruxelles: European Commission.

European Commission, 20I3b. VAT Rates Applied in the Member States of the European Union - Situation at I4th January 20I3. Bruxelles: European Commission.

European Commission: Taxation and Customs Union. Taxes in Europe baza podataka. Bruxelles: European Commission.

Eurostat baza podataka. Dostupno na: [http://epp.eurostat.ec.europa.eu/portal/page/portal/statistics /search_database].

Global Health Observatory baza podataka. Global Information System on Alcohol and Health - Levels of Consumption. Dostupno na: [http://apps.who.int/gho/data/].

High Level Group on Fraud in the Tobacco and Alcohol Sectors, 1998. Report to Directors General for Customs and Indirect Taxation. 
Kuliš, D., 2005. Trošarine na alkohol i alkoholna pića u: D. Kuliš. Plaćamo li Europske trošarine? Zagreb: Institut za javne financije/Zaklada Friedrich Ebert, 3I-4I.

Kuliš, D., 20I3. Sustav trošarina u Hrvatskoj bliži europskom sustavu. Newsletter, br. 75. Zagreb: Institut za javne financije

London Economics, 2010. Study analysing possible changes in the minimum rates and structures of excise duties on alcoholic beverages. Final Report to EC DG Taxation and Customs Union.

Ministarstvo financija Republike Hrvatske. Vremenske serije podataka. Zagreb: Ministarstvo financija.

Proposal for Council Directive amending Directive 92/84/EEC on the approximation of the rates of excise duty on alcohol and alcoholic beverages.

Rabinovich, L. [et al.], 20I2. Further study on the affordability of alcoholic beverages in the EU. Bruxelles: European Commission.

Segebarth, N. [et al.], 2008. Analysis and Characterisation of Alcoholic Products (ACAP). FISCALIS Project Group - Final Report. Luxembourg: Office for Official Publications of the European Communities.

Smith, S., 2005. Economic Issues in Alcohol taxation u: S. Cnossen, ur. Theory and Practice of Excise Taxation, 56-83. New York: Oxford University Press Inc.

The Brewers of Europe, 2012. Excise Duty Rates for Beer in Europe - Rates as at: I October 2012.

WHO, 2012. Alcohol in the European Union - Consumption, harm and policy approaches. Copenhagen: WHO Regional Office for Europe.

Zakon o trošarinama, NN 83/o9, I/IO, III/I2 i 22/I3. Zagreb: Narodne novine. 


\section{DODATAK - USPOREDBA OPĆIH STOPA TROŠARINA PO ZEMLJAMA ${ }^{7}$}

\section{Grafikon DI.}

Propisane i prilagođene opće stope trošarina na pivo, izražene u eurima po hektolitru, važeće I. siječnja 20I3. ${ }^{8}$

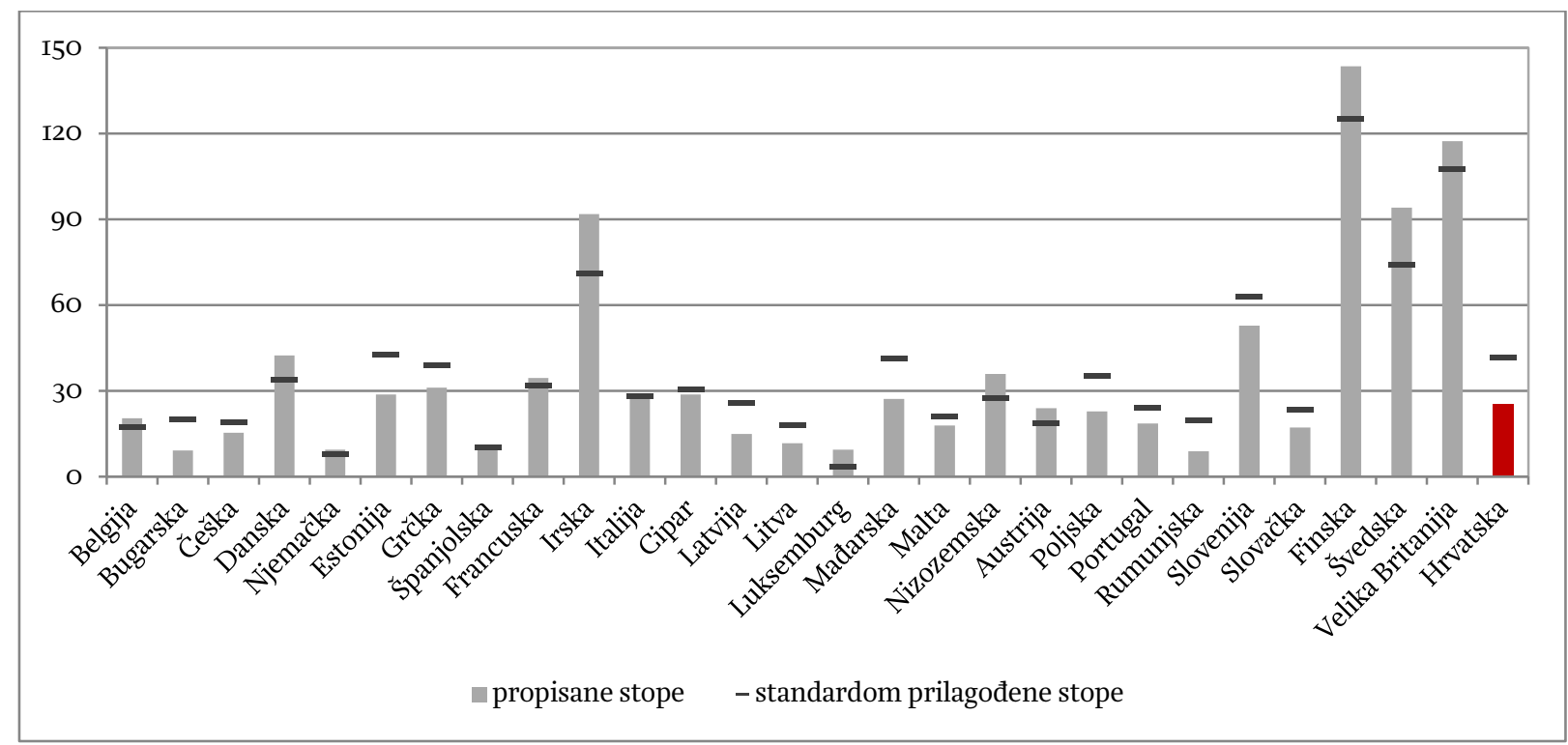

Izvor: European Commission (2013a); izračun autora

\section{Grafikon D2.}

Propisane i prilagođene opće stope trošarina na mirna vina, u eurima po hektolitru, važeće I. siječnja 2013.

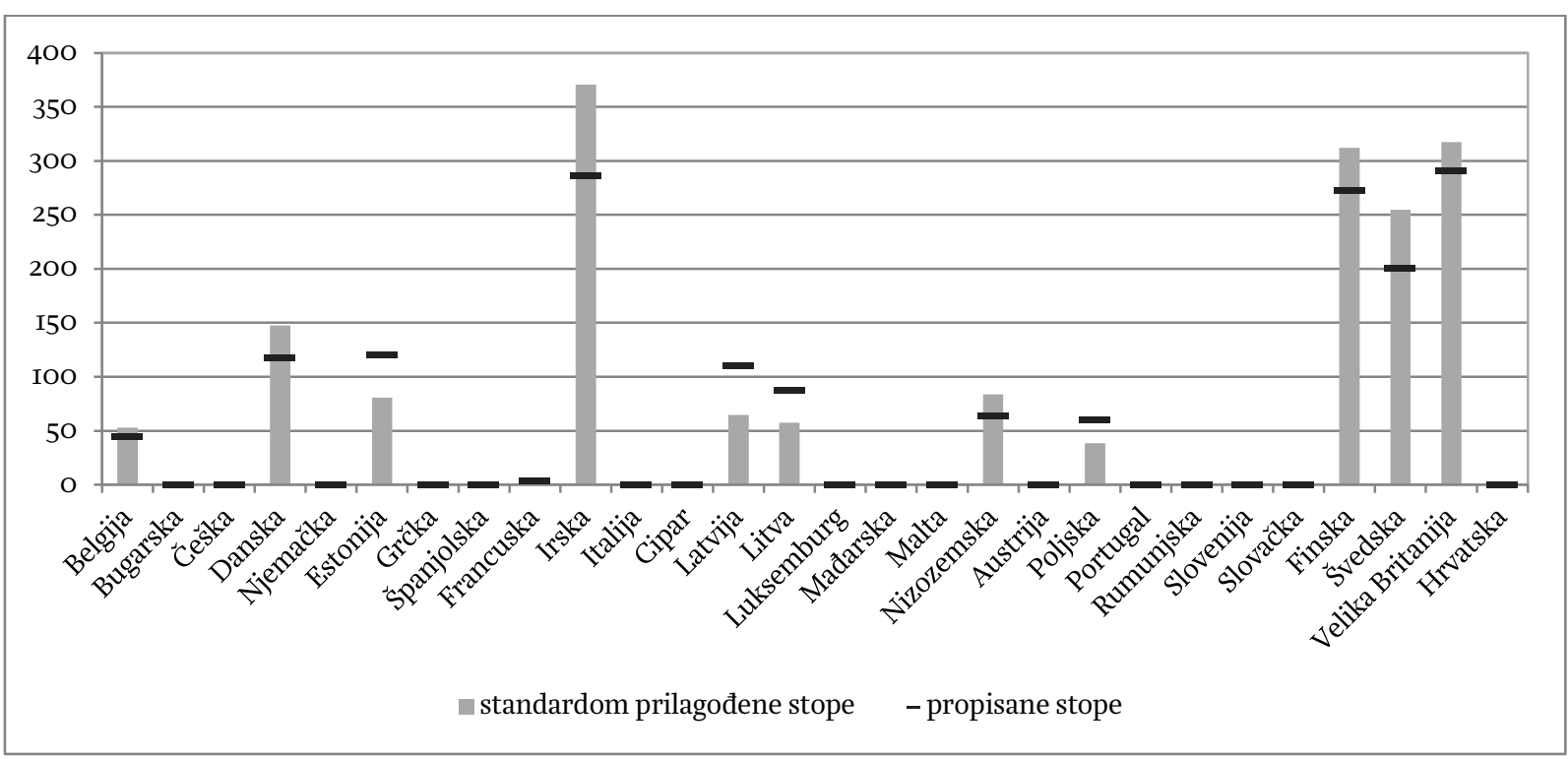

Izvor: European Commission (2013a); izračun autora

\footnotetext{
${ }^{7}$ U grafikonima Di - D5 standardom prilagođena stopa dobivena je dijeljenjem propisane stope trošarine BDP-om po stanovniku, mjerenog standardom kupovne moći (EU-27=I). Na taj se način dobiva usporediva slika iznosa trošarina po zemljama, koja uzima u obzir i razlike u standardu pojedinih zemalja.

${ }^{8}$ Za potrebe usporedivosti stopa po zemljama, uzete su stope po hektolitru za prosječnu jačinu piva s koncentratom ekstrakta u sladovini od I2 ili s volumnim udjelom alkohola od 4,8\% vol. (The Brewers of Europe, 2OI2).
} 


\section{Grafikon D3.}

Propisane i prilagođene opće stope trošarina na pjenušava vina, u eurima po hektolitru, važeće I. siječnja 2013.

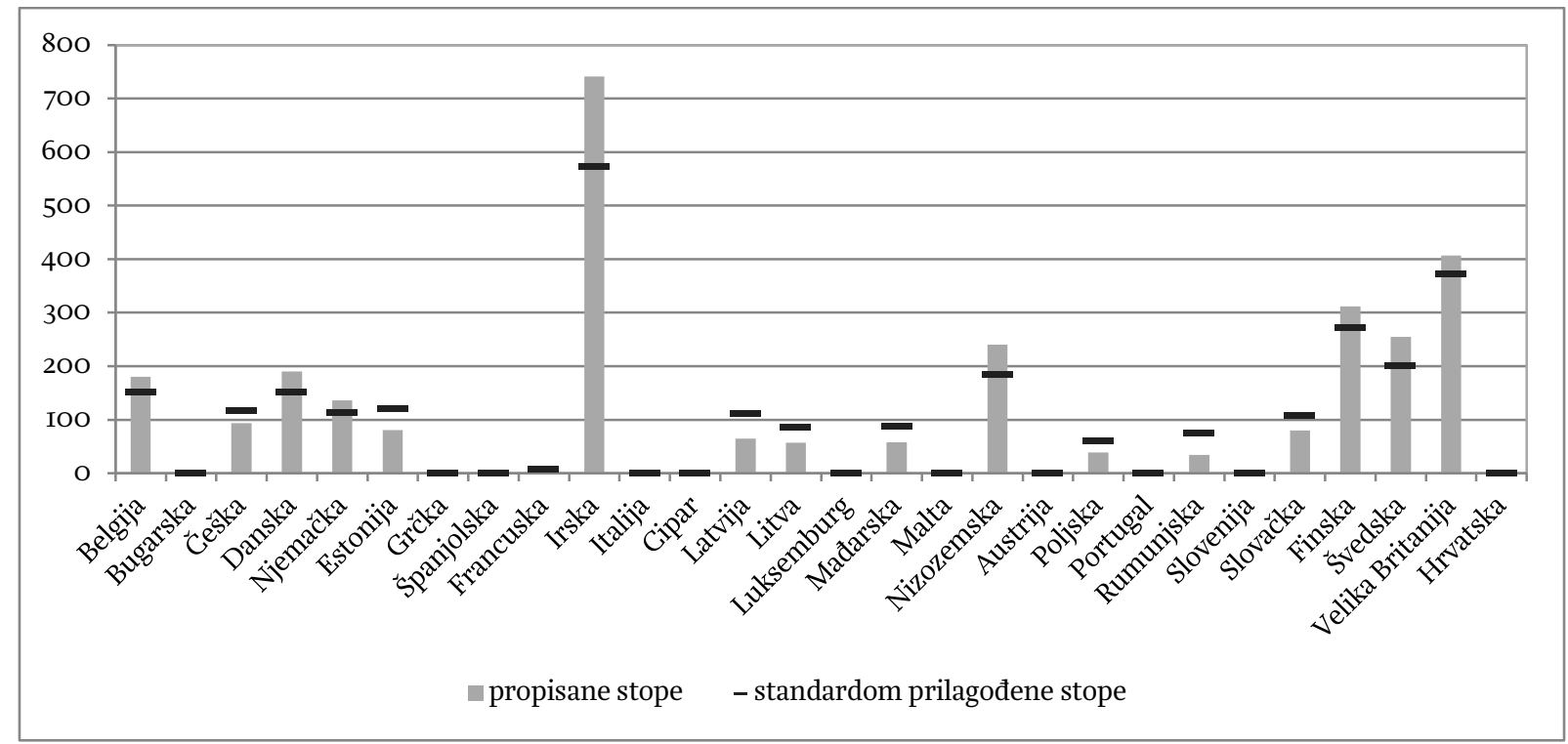

Izvor: European Commission (2013a); izračun autora

\section{Grafikon D4.}

Propisane i prilagođene opće stope trošarina na međuproizvode, u eurima po hektolitru, važeće I. siječnja 2013.

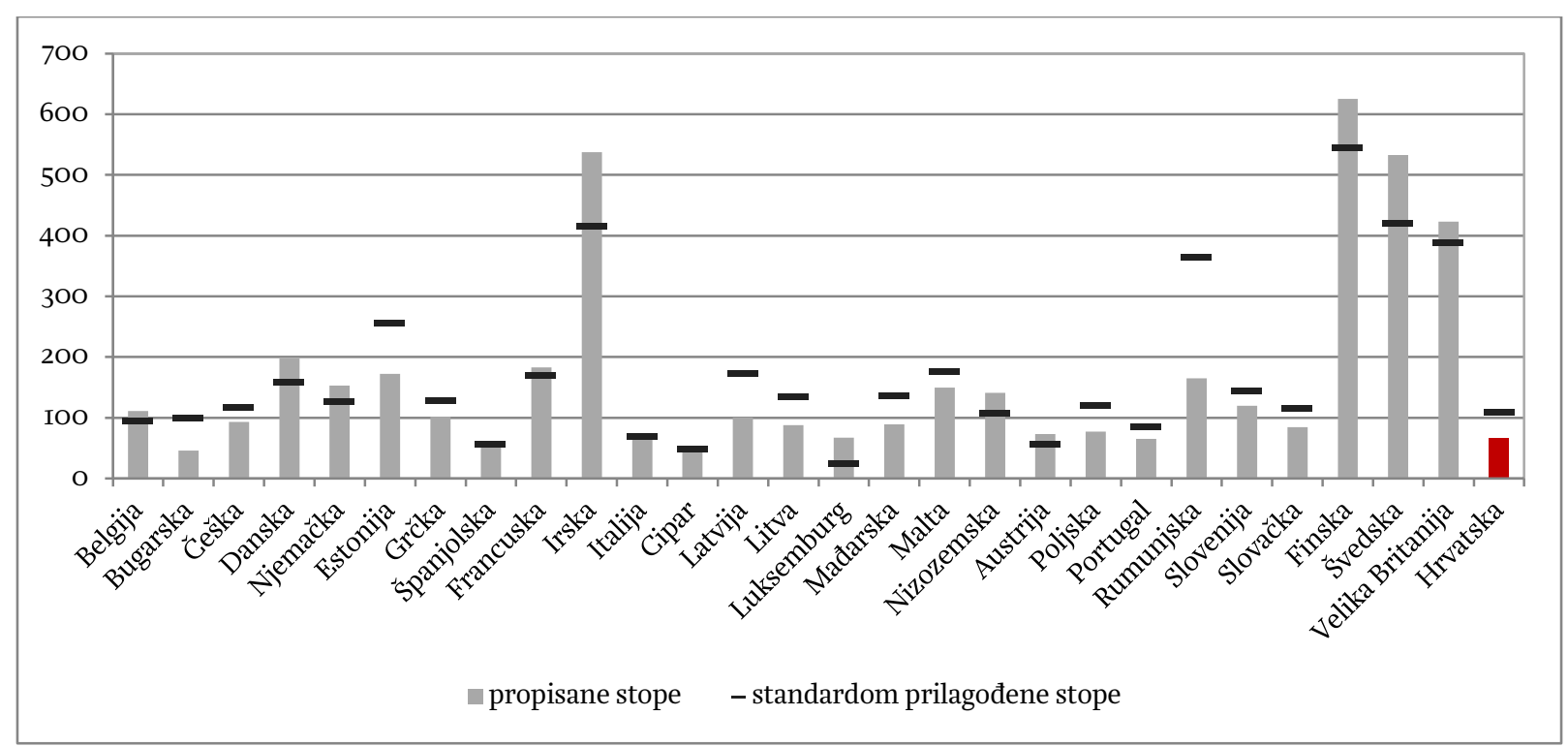

Izvor: European Commission (2013a); izračun autora 


\section{Grafikon D5.}

Propisane i prilagođene opće stope trošarina na etilni alkohol, u eurima po hektolitru čistog alkohola, važeće I. siječnja 2013.

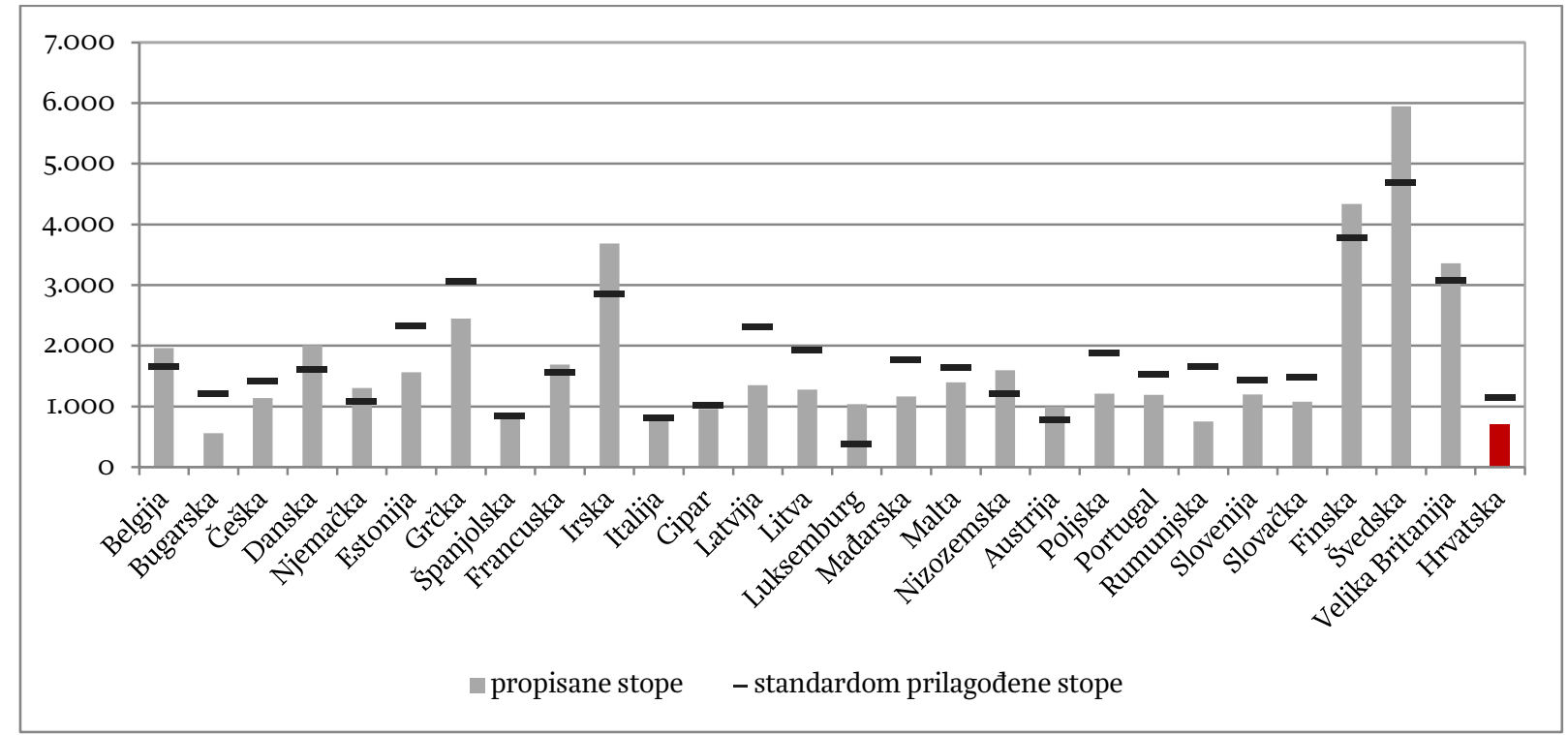

Izvor: European Commission (2013a); izračun autora

I4 NEWSLETTER 76 | PETAR SOPEK | Sustav oporezivanja alkohola u Europskoj uniji i Hrvatskoj | Institut za javne financije | 